\section{Kidney \\ Blood Pressure Research}

Kidney Blood Press Res 2013;37:547-556

DOI: $10.1159 / 000355735$

Published onlıne: November 19, 2013

Accepted: September 25, 2013

This is an Open Access article licensed under the ter

\title{
Down-Regulation of the $\mathrm{Na}^{+}$-Coupled Phosphate Transporter NaPi-IIa by AMP- Activated Protein Kinase
}

\author{
Miribane Dërmaku-Sopjania ${ }^{a, b, f} \quad$ Ahmad Almilaji ${ }^{a}, f$ Tatsiana Pakladok ${ }^{a}$ \\ Carlos Munoz ${ }^{\mathrm{a}, \mathrm{e}}$ Zohreh Hosseinzadeha María Blecuaa,d Mentor Sopjania,c \\ Florian Lang ${ }^{\mathrm{a}}$
}

\begin{abstract}
aUniversity of Tübingen, Department of Physiology, Tübingen, Germany; ${ }^{b}$ Department of Chemistry, 'Faculty of Medicine, University of Prishtina, Prishtinë, Kosova; ${ }^{\mathrm{d} F a c u l t a d}$ de Biología, Ciencias Ambientales y Química, Edificio Polivalente, Universidad de Alcalá, Alcalá de Henares, Madrid, Spain; eInstitute of Physiology and Zurich Center for Integrative Human Physiology (ZIHP), University of Zurich, Zurich, Switzerland; ' contributed equally and thus share first authorship
\end{abstract}

\section{Key Words}

Energy depletion $\bullet$ Phosphate transport $\bullet$ Compound C $\bullet$ Kidney

\begin{abstract}
Background/Aims: The $\mathrm{Na}^{+}$-coupled phosphate transporter $\mathrm{NaPi}-\mathrm{Ila}$ is the main carrier accomplishing renal tubular phosphate reabsorption. It is driven by the electrochemical $\mathrm{Na}^{+}$ gradient across the apical cell membrane, which is maintained by $\mathrm{Na}^{+}$extrusion across the basolateral cell membrane through the $\mathrm{Na}^{+} / \mathrm{K}^{+}$ATPase. The operation of $\mathrm{NaPi}$-Ila thus requires energy in order to avoid cellular $\mathrm{Na}^{+}$accumulation and $\mathrm{K}^{+}$loss with eventual decrease of cell membrane potential, $\mathrm{Cl}^{-}$entry and cell swelling. Upon energy depletion, early inhibition of $\mathrm{Na}^{+}-$ coupled transport processes may delay cell swelling and thus foster cell survival. Energy depletion is sensed by the AMP-activated protein kinase (AMPK), a serine/threonine kinase stimulating several cellular mechanisms increasing energy production and limiting energy utilization. The present study explored whether AMPK influences the activity of NAPi-IIa. Methods: CRNA encoding NAPi-IIa was injected into Xenopus oocytes with or without additional expression of wildtype AMPK (AMPK ${ }^{\alpha 1}-\mathrm{HA}+\mathrm{AMPK}^{\beta 1}$-Flag+AMPK $\left.{ }^{\vee 1}-\mathrm{HA}\right)$, of inactive $\mathrm{AMPK}^{\alpha K 45 R}\left(\mathrm{AMPK}^{\alpha 1 K^{445 R}}+\mathrm{AMPK}^{\beta 1}\right.$ Flag+AMPK $\left.{ }^{\vee 1}-H A\right)$ or of constitutively active $A M P K^{\vee R 70 Q}\left(A M P K^{\alpha 1}-H A+A M P K^{\beta 1}-F l a g+A M P K \gamma 1^{R 70 Q}\right)$. $\mathrm{NaPi}$-IIa activity was estimated from phosphate-induced current in dual electrode voltage clamp experiments. Results: In NaPi-IIa-expressing, but not in water-injected Xenopus oocytes, the addition of phosphate $(1 \mathrm{mM})$ to the extracellular bath solution generated a current $\left(\mathrm{I}_{\mathrm{p}}\right)$, which was significantly decreased by coexpression of wild-type AMPK and of AMPK ${ }^{\mathrm{R} 70 Q}$ but not of
\end{abstract}




\section{Kidney \\ Blood Pressure Research}

AMPK $^{\text {aK45R }}$. The phosphate-induced current in NaPi-IIa- and AMPK-expressing Xenopus ooocytes was significantly increased by AMPK inhibitor Compound C $(20 \mu \mathrm{M})$. Kinetic analysis revealed that AMPK significantly decreased the maximal transport rate. Conclusion: The AMP-activated protein kinase AMPK is a powerful regulator of $\mathrm{NaPi}$-IIa and thus of renal tubular phosphate transport.

Copyright $\odot 2013$ S. Karger AG, Basel

\section{Introduction}

The AMP-activated protein kinase (AMPK) senses the cytosolic AMP/ATP concentration ratio and thus the energy status of the cell $[1,2]$. When activated by energy deficiency, AMPK stimulates several cellular functions serving ATP generation [3], such as cellular glucose uptake, glycolysis, fatty acid oxidation and up-regulation of enzymes required for ATP production [2, 4-6]. AMPK further inhibits energy-utilizing mechanisms including protein synthesis, gluconeogenesis and lipogenesis [2-4]. The kinase thus protects against cell death during energy depletion $[3,7,8]$.

In renal proximal tubules, energy is mainly utilized by transepithelial transport [9]. $\mathrm{Na}^{+}-$ coupled transport processes are driven by the electrochemical gradient for $\mathrm{Na}^{+}$, which is maintained by the energy-consuming $\mathrm{Na}^{+} / \mathrm{K}^{+}$ATPase in the basolateral cell membrane [10]. Energy depletion is expected to impair the activity of the $\mathrm{Na}^{+} / \mathrm{K}^{+}$ATPase with eventual dissipation of the $\mathrm{Na}^{+}$and $\mathrm{K}^{+}$gradients, depolarization of the cell membrane, cellular accumulation of $\mathrm{Cl}$, osmotic water entry and thus cell swelling [11]. $\mathrm{Na}^{+}$-coupled carriers include the $\mathrm{Na}^{+}$-coupled phosphate transporter NaPi-IIa (SLC34A1), the most important carrier accomplishing renal tubular phosphate transport across the apical brush border membrane of proximal renal tubules [12-14]. Renal tubular phosphate reabsorption is regulated by a wide variety of parameters, such as dietary phosphate intake, acid-base status, parathyroid hormone, 1,25$(\mathrm{OH})_{2}$ vitamin $\mathrm{D}_{3}, \mathrm{FGF}-23$, insulin and insulin-like growth factor IGF1 [15-21]. Signaling involved in the regulation of NaPi-IIa includes the protein kinases $\mathrm{A}$ and $\mathrm{C}, \mathrm{ERK} 1 / 2$, Klotho and the PI3K/PKB/GSK3 kinase cascade [22-29]. Nothing is known, however, about the potential regulation of NaPi-IIa by AMPK. The present study thus explored whether AMPK regulates NaPi-IIa.

\section{Materials and Methods}

\section{Constructs}

For generation of cRNA [30], constructs were used encoding wild-type NaPi-Ila [31], wild-type AMPK $\left(\mathrm{AMPK}^{\alpha 1}\right.$-HA+AMPK ${ }^{\beta 1}$-Flag+AMPK ${ }^{\gamma 1}$-HA $)[32,33]$, constitutively-active AMPK ${ }^{\gamma 70 Q}$-HA $\left(\mathrm{AMPK}^{\alpha 1}-\mathrm{HA}+\mathrm{AMPK}^{\beta 1}\right.$ Flag + AMPK $\left.{ }^{\gamma 1 \mathrm{R} 700}\right)[34]$ and kinase dead mutant AMPK ${ }^{\alpha 45 R}-\mathrm{HA}\left(\mathrm{AMPK}^{\alpha 1 \mathrm{~K} 45 \mathrm{R}}+\mathrm{AMPK}^{\beta 1}-\right.$ Flag + AMPK $\left.{ }^{\gamma 1}-\mathrm{HA}\right)$ [35]. The cRNA encoding wild type NaPi-IIa or encoding AMPK was synthesized as described previously [36].

\section{Voltage clamp in Xenopus oocytes}

Dissection of Xenopus laevis ovaries, collection and handling of the oocytes have been described elsewhere [37]. Oocytes were injected with $15 \mathrm{ng}$ of cRNA encoding NaPi-IIa on the first day with or without 4.6 ng of cRNA encoding either AMPK ${ }^{\alpha 1}$-HA+AMPK ${ }^{\beta 1}$-Flag+AMPK ${ }^{11}-\mathrm{HA}$ (wild-type AMPK), or AMPK ${ }^{\alpha 1}-\mathrm{HA}+\mathrm{AMPK}^{\beta 1}$ Flag + AMPK ${ }^{\gamma R 70 Q}$ (constitutively-active $A M P K^{\gamma R 70 Q}$ ) or AMPK ${ }^{\alpha K^{K}}{ }^{-H A}+\mathrm{AMPK}^{\beta 1}$-Flag +AMPK ${ }^{\gamma 1}$-HA (kinase-dead mutant $\mathrm{AMPK}^{\alpha \mathrm{K} 45 \mathrm{R}}$ ] on the second day after preparation of Xenopus laevis oocytes [38]. For control, the oocytes were injected with the respective volumes of DEPC-treated water. Therefore, the number of injections and the injected total volume were equal in all oocytes. The electrophysiological experiments were performed at room temperature 3-4 days after the second injection. Where indicated, oocytes were incubated with AMPK activator AICAR (1 mM, Tocris Bioscience, Bristol, UK) or AMPK inhibitor compound C (20 $\mu$ M, Calbiochem, Bad Soden, Germany) for the last 24 hours before the measurement. Oocytes were maintained at $17^{\circ} \mathrm{C}$ in ND96-A solution 


\section{Kidney Blood Pressure Research}

containing $88.5 \mathrm{mM} \mathrm{NaCl}, 2 \mathrm{mM} \mathrm{KCl}, 1.8 \mathrm{mM} \mathrm{CaC1}_{2}, 1 \mathrm{mM} \mathrm{MgC1} 1_{2}, 5 \mathrm{mM}$ HEPES, $0.11 \mathrm{mM}$ tretracycline (Sigma, Schnelldorf, Germany) , $4 \mu \mathrm{M}$ ciprofloxacin (Fresenius Kabi, Graz, Austria), 0.22 mM refobacin (Merck-Serono, Darmstadt, Germany), $0.5 \mathrm{mM}$ theophylline (Takeda, Singen, Germany) as well as $5 \mathrm{mM}$ sodium pyruvate. The $\mathrm{pH}$ was adjusted to 7.4 by adding $\mathrm{NaOH}$. Two electrode voltage-clamp recordings were performed at a holding potential of $-50 \mathrm{mV}$. The flow rate of the superfusion was $20 \mathrm{ml} / \mathrm{min}$, and a complete exchange of the bath solution was reached within about $10 \mathrm{~s}[39,40]$. The data were filtered at $10 \mathrm{~Hz}$ and recorded with a Digidata 1322A A/D-D/A converter and Clampex V.4.02 software for data acquisition and analysis (Axon Instruments, Union City, CA, USA). The data were analyzed with Clampfit V. 9.0.1.07 software (Axon Instruments).

Detection of NaPi-IIa cell surface expression by chemiluminescence

Oocytes were incubated for 20 min in ND96 with $1 \%$ BSA at $4{ }^{\circ} \mathrm{C}$ to block nonspecific antibody binding. Then, oocytes were incubated with primary rabbit anti-human SLC34A1 (NaPi-IIa) polyclonal antibody (diluted 1:500, Life Span Biosciences, WA, USA) for $1 \mathrm{~h}$ at $4^{\circ} \mathrm{C}$ and subsequently with secondary, HRP-conjugated goat anti-rabbit IgG antibody (1:1000, Cell Signaling Technology, Frankfurt, Germany). Oocytes were washed 3 times for 5 min in 1\% BSA/ND96 and then 3 times in ND96 without BSA for 5 min at $4^{\circ} \mathrm{C}$. Individual oocytes were placed in 96 well plates with $20 \mu \mathrm{l}$ of SuperSignal ELISA Femto Maximum Sensitivity Substrate (Pierce, Rockford, IL, USA) and chemiluminescence of single oocytes was quantified in a luminometer (Walter Wallac 2 plate reader, Perkin Elmer, Juegesheim, Germany) by integrating the signal over a period of $1 \mathrm{~s}$. Results display normalized relative light units. Integrity of the measured oocytes was assessed by visual control after the measurement to avoid unspecific light signals from the cytosol.

\section{Statistical analysis}

Data are provided as means \pm SEM, $n$ represents the number of oocytes investigated. All experiments were repeated with at least 3 batches of oocytes. In all repetitions qualitatively similar data were obtained. Data were tested for significance using ANOVA, and results with $P<0.05$ were considered statistically significant.

\section{Results}

In order to test, whether AMP-activated protein kinase (AMPK) regulates the electrogenic phosphate transporter NaPi-IIa, Xenopus oocytes were injected with cRNA encoding NaPi-IIa with or without additional injection of cRNA encoding wild-type AMPK. The electrogenic phosphate transport was minimal in water-injected Xenopus oocytes (Fig. 1). In Xenopus oocytes expressing NaPi-IIa, however, phosphate $(1 \mathrm{mM})$ induced an inward current (Ip) reflecting electrogenic entry of $\mathrm{Na}^{+}$and phosphate. Ip was significantly decreased by additional coexpression of wild-type AMPK (AMPK ${ }^{\alpha 1}-\mathrm{HA}+\mathrm{AMPK}^{\beta 1}$-Flag+AMPK ${ }^{\gamma 1}$-HA; Fig. 1). Accordingly, wild-type AMPK inhibited NaPi-IIa activity.

To further characterize the AMPK effect on the phosphate-induced current in Xenopus oocytes, we performed kinetic analysis (Fig. 2). In Xenopus oocytes expressing NaPi-IIa alone, the maximal current approached $12.2 \pm 0.6 \mathrm{nA}(\mathrm{n}=7)$ and the phosphate concentration needed for halfmaximal current $\left(\mathrm{K}_{\mathrm{M}}\right) 33.9 \pm 11.2 \mu \mathrm{M}(\mathrm{n}=7)$. In Xenopus oocytes expressing $\mathrm{NaPi}$-IIa together with wild-type AMPK $\left(\mathrm{AMPK}^{\alpha 1}-\mathrm{HA}+\mathrm{AMPK}^{\beta 1}\right.$-Flag+AMPK ${ }^{\gamma 1}$-HA) the maximal transport rate approached $5.5 \pm 0.5 \mathrm{nA}(\mathrm{n}=7)$ and the phosphate concentration needed for halfmaximal current $\left(\mathrm{K}_{\mathrm{M}}\right) 73 \pm 40 \mu \mathrm{M}(\mathrm{n}=7)$. Accordingly, coexpression of AMPK decreased the maximal transport rate without significantly modifying $\mathrm{K}_{\mathrm{M}}$.

Further experiments explored whether the effect of wild type AMPK on NaPi-IIa requires kinase activity. To this end, NaPi-IIa was expressed in Xenopus oocytes with or without additional expression of constitutively-active $\mathrm{AMPK}^{\gamma \mathrm{R} 70 \mathrm{Q}}\left(\mathrm{AMPK}^{\alpha 1}-\mathrm{HA}+\mathrm{AMPK}^{\beta 1}\right.$-Flag $\left.+\mathrm{AMPK}^{\gamma 1 \mathrm{R} 700}\right)$ or of the catalytically-inactive mutant $\mathrm{AMPK}^{\alpha \mathrm{K} 45 \mathrm{R}}\left(\mathrm{AMPK}^{\alpha 1 K 45 \mathrm{R}}+\mathrm{AMPK}^{\beta 1}-\right.$ Flag + $\mathrm{AMPK}^{\gamma 1}$-HA). As shown in Fig. 3, the electrogenic phosphate transport in NaPi-IIa-expressing Xenopus oocytes was markedly decreased by the coexpression of constitutively active $\mathrm{AMPK}^{\gamma \mathrm{R} 70 \mathrm{Q}}$. In contrast, coexpression of catalytically-inactive $\mathrm{AMPK}^{\alpha \mathrm{K} 45 \mathrm{R}}$ did not significantly modify Ip in NaPi-IIa expressing Xenopus oocytes. 


\section{Kidney \\ Blood Pressure Research}

Fig. 1. Coexpression of AMPK downregulated electrogenic phosphate transport in NaPi-Ila-expressing Xenopus oocytes. A: Representative original tracings showing the phosphate (1 mM)-induced current $\left(\mathrm{I}_{\mathrm{p}}\right)$ in Xenopus oocytes injected with water (1) or expressing NaPi-IIa without (2) or with (3) additional coexpression of wild type AMPK. Following removal of extracellular phosphate, the current gradually returned to basal levels. B: Arithmetic means \pm SEM of the normalized phosphate $(1 \mathrm{mM})$-induced

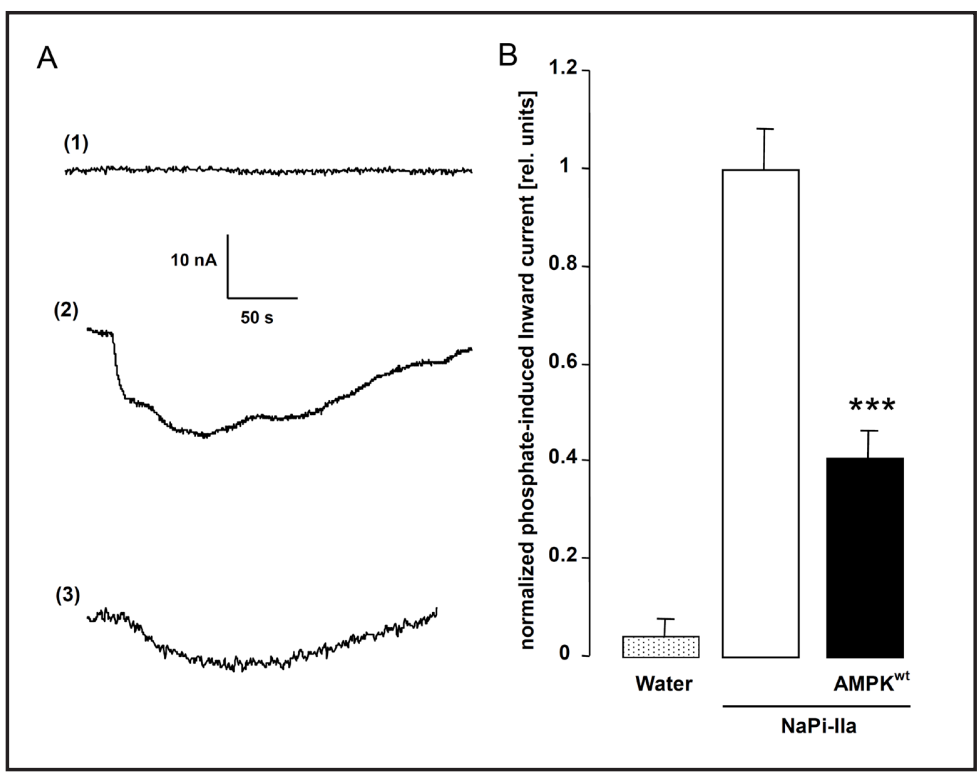
current $\left(\mathrm{I}_{\mathrm{p}}\right)$ in Xenopus oocytes injected with water (dotted bar, $n=3$ ) or expressing NaPi-IIa without (white bar, $n=11$ ) or with (black bar, $n=11)$ additional coexpression of wild type AMPK ${ }^{\mathrm{wt}}$. $* * *$ indicates statistically significant difference $(p<$ 0.001) from current in Xenopus oocytes expressing NaPi-IIa alone.

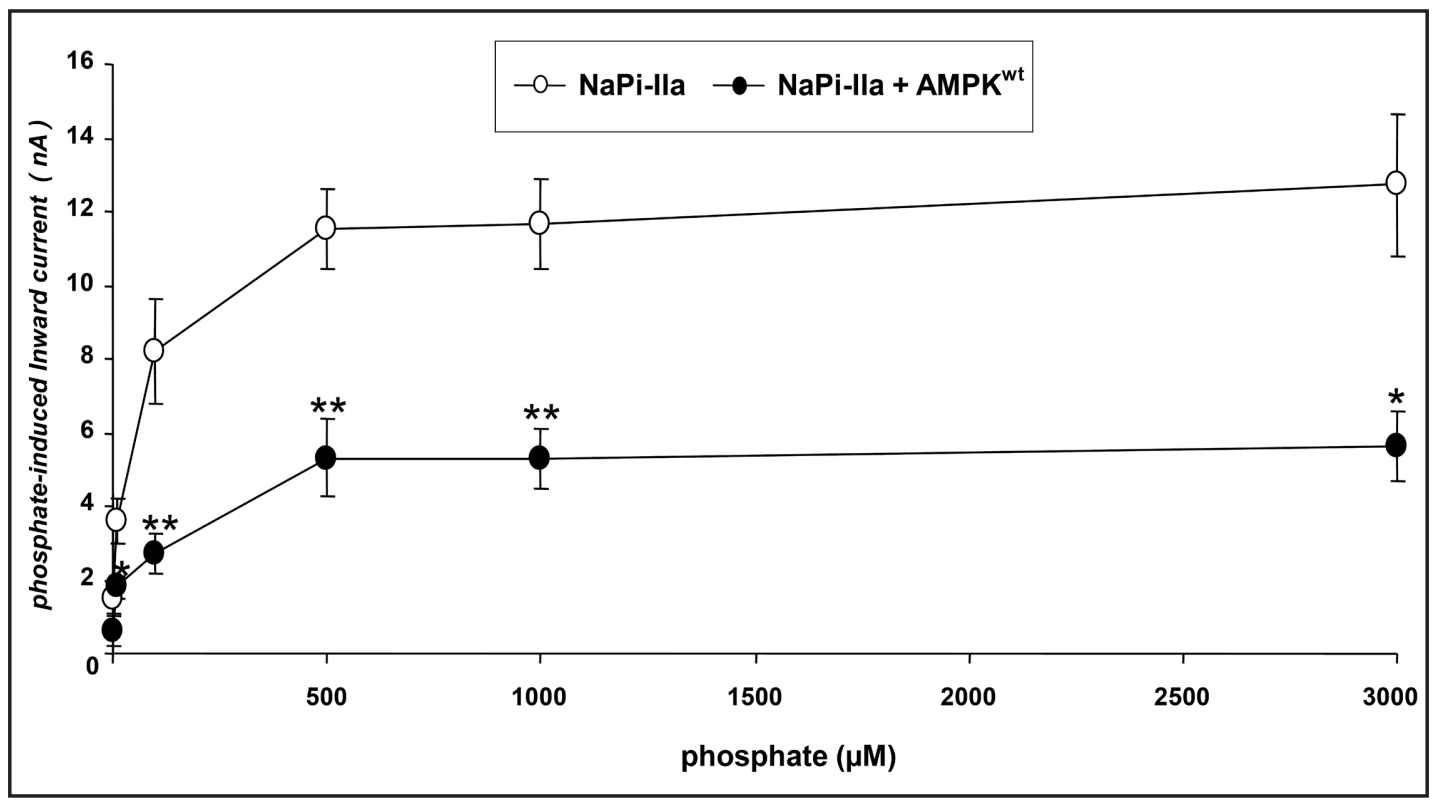

Fig. 2. Wild-type AMPK decreased the maximal current in NaPi-IIa-expressing Xenopus oocytes without significantly affecting affinity. Arithmetic means \pm SEM of phosphate-induced current $\left(\mathrm{I}_{\mathrm{p}}\right)$ as a function of phosphate concentration in Xenopus oocytes expressing NaPi-IIa without (white circles, $\mathrm{n}=7$ ) or with additional coexpression of $\mathrm{AMPK}^{\mathrm{wt}}$ (black circles, $\left.\mathrm{n}=7\right)$. *, ** indicate statistically significant difference $(\mathrm{p}<0.05$, $\mathrm{p}<0.01$ ) from current in Xenopus oocytes expressing NaPi-IIa alone.

In order to investigate whether the AMPK influences NaPi-IIa surface expression, we used chemiluminescence for determination of membrane NaPi-IIa protein abundance. As 


\section{Kidney Blood Pressure Research}

Fig. 3. Constitutively active AMPKK $^{\gamma \mathrm{R} 70 \mathrm{Q}}$ but not inactive AMPK $^{\alpha K 45 R}$ decreased the current in NaPiIIa-expressing Xenopus oocytes. A: Representative original tracings of phosphate-induced current $\left(\mathrm{I}_{\mathrm{P}}\right)$ in Xenopus oocytes injected with water (1), expressing NaPi-
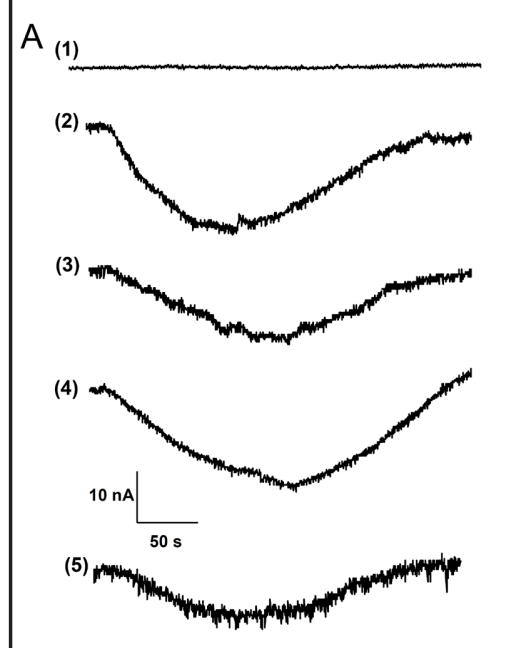

B

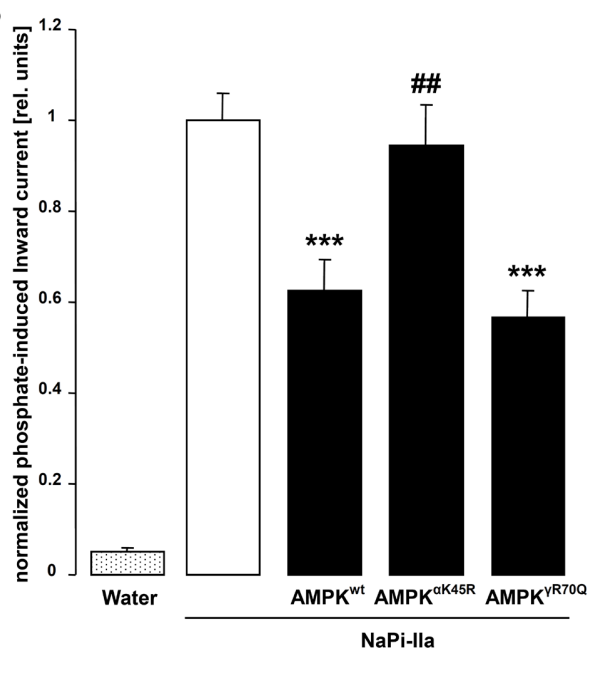

IIa alone (2) or expressing NaPi-IIa with additional coexpression of wild-type AMPK (3), kinase-dead mutant $\mathrm{AMPK}^{\mathrm{K} 45 \mathrm{R}}(4)$ or constitutively active $\mathrm{AMPK}^{\mathrm{R} 70 Q}(5)$. B: Arithmetic means $\pm \mathrm{SEM}(n=17-34)$ of the normalized phosphate-induced current $\left(\mathrm{I}_{\mathrm{p}}\right)$ in Xenopus oocytes injected with water (dotted bar, $n=17$ ), expressing NaPiIIa alone (white bar, $n=34)$ or expressing NaPi-IIa with additional coexpression of wild-type AMPK $\left(1^{\text {st }}\right.$ black bar, $n=24)$, of kinase-dead mutant $\mathrm{AMPK}^{\alpha \mathrm{K} 45 \mathrm{R}}\left(2^{\text {nd }}\right.$ black bar, $\left.n=19\right)$ or of constitutively active $\mathrm{AMPK}^{\gamma \mathrm{R} 70 \mathrm{Q}}\left(3^{\text {rd }}\right.$ black bar, $n=24) .{ }^{* * *}(\mathrm{p}<0.001)$ indicates statistically significant difference from Xenopus oocytes expressing NaPi-IIa alone, \#\# $(\mathrm{p}<0.01)$ indicates statistically significant difference from Xenopus oocytes expressing NaPiIIa and wild-type AMPK.

Fig. 4. Constitutively active $A M P K^{\gamma R 70 Q}$ but not inactive $\mathrm{AMPK}^{\alpha \mathrm{K} 45 \mathrm{R}}$ decreased NaPi-Ila membrane expression in Xenopus oocytes. Arithmetic means \pm SEM $(n=60-82)$ of the normalized intensity of the NaPi-IIa-dependent chemiluminescence in Xenopus oocytes injected with water (dotted bar, $n=60$ ), expressing NaPi-IIa alone (white bar, $n=82$ ) or expressing NaPi-IIa with additional coexpression of constitutively active $\mathrm{AMPK}^{\gamma \mathrm{R} 70 \mathrm{Q}}\left(1^{\text {st }}\right.$ black bar, $n=75$ ) or of kinase-dead mutant $\mathrm{AMPK}^{\alpha \mathrm{K} 45 \mathrm{R}}$ $\left(2^{\text {nd }}\right.$ black bar, $\left.n=66\right) .{ }^{* *}(\mathrm{p}<0.01)$ indicates statistically significant difference from Xenopus oocytes expressing NaPi-IIa alone, $\#(\mathrm{p}<0.05)$ indicates statistically significant difference from Xenopus oocytes expressing NaPi-IIa and wild-type AMPK.

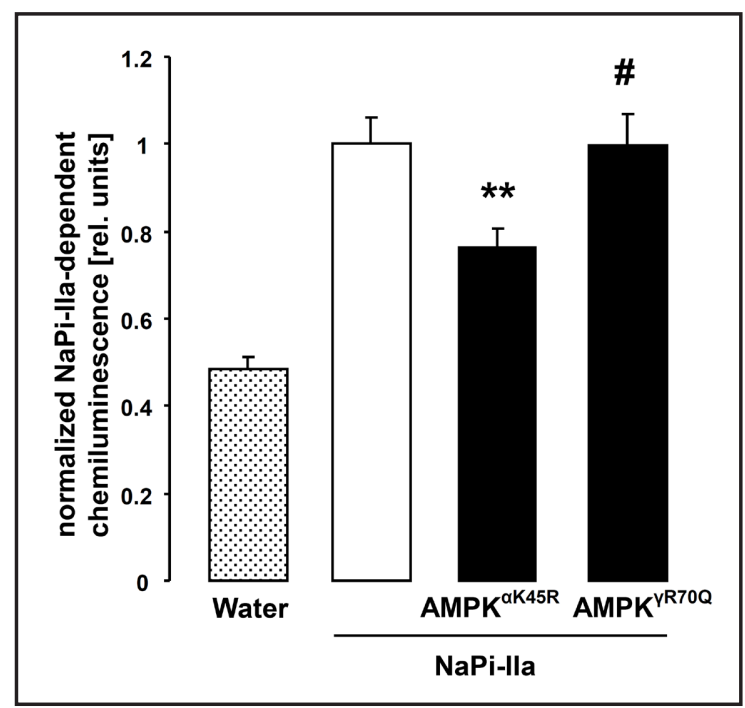

shown in Fig. 4, constitutively active AMPK ${ }^{\gamma \mathrm{R} 70 \mathrm{Q}}$ significantly decreased Napi-IIa cell membrane abundance, an effect not mimicked by catalytically-inactive $\mathrm{AMPK}^{\alpha \mathrm{K} 45 \mathrm{R}}$.

Finally, we tested whether pharmacological manipulation of AMPK activity similarly influences NaPi-IIa activity. As shown in Fig. 5, a 24 hours exposure of NaPi-IIa-expressing Xenopus oocytes to AMPK activator AICAR mimicked the effect of AMPK coexpression. Furthermore, AMPK inhibitor Compound $\mathrm{C}$ abrogated the stimulatory effect of AMPK coexpression on NaPiIIa activity (Fig. 5). 


\section{Kidney \\ Blood Pressure \\ Research}

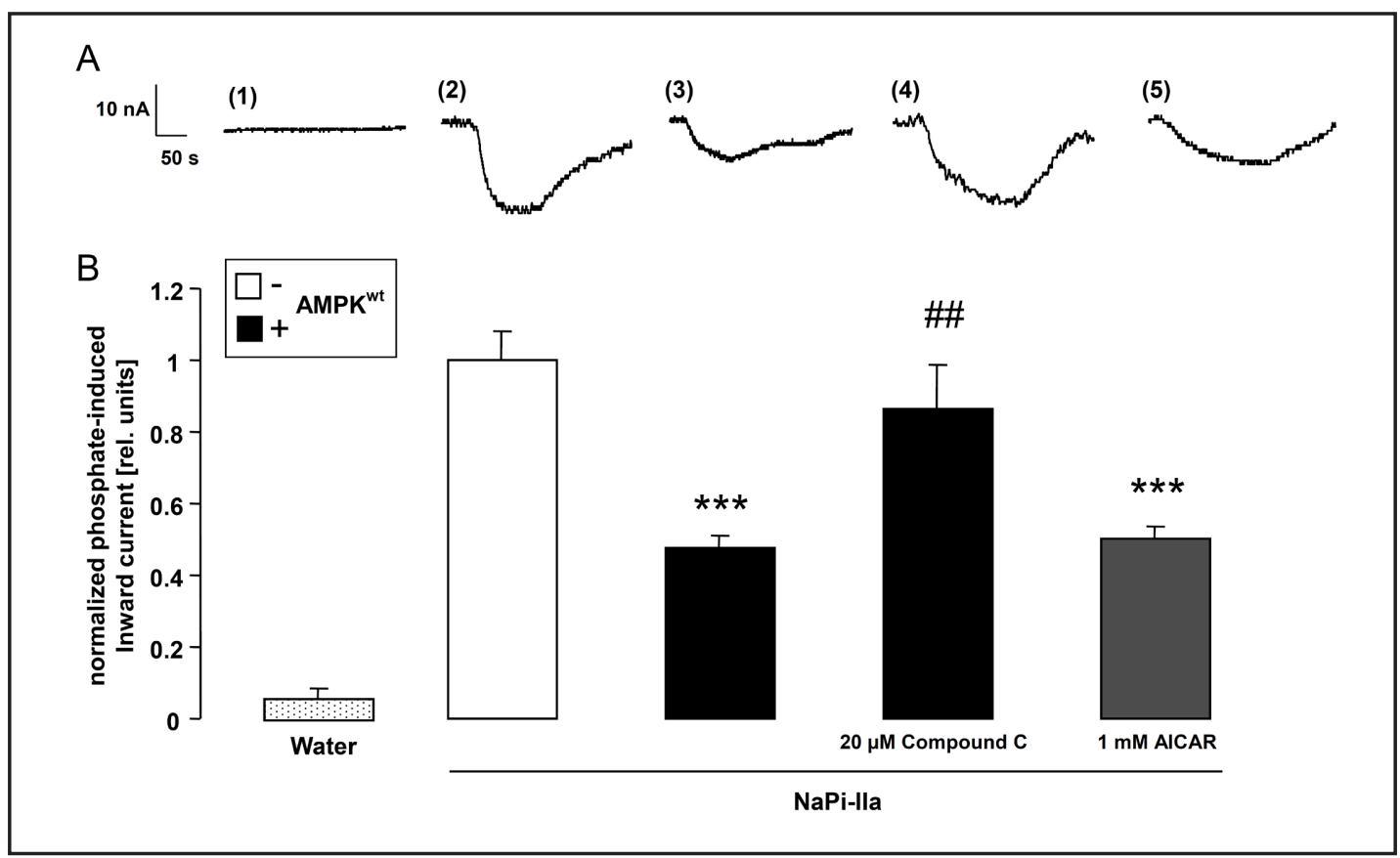

Fig. 5. Pharmacological activation of AMPK decreased the current in NaPi-IIa-expressing Xenopus oocytes. A: Representative original tracings showing currents in Xenopus oocytes injected with water (1), or expressing NaPi-IIa alone (2) or expressing NaPi-IIa with additional coexpression of wild-type AMPK and incubated for 24 hours without (3), or with (4) $20 \mu \mathrm{M}$ Compound C or expressing NaPi-IIa alone and incubated for 24 hours with 1 mM AICAR (5). B: Arithmetic means \pm SEM $(n=10-20)$ of the normalized phosphate-induced current $\left(\mathrm{I}_{\mathrm{p}}\right.$ ) in Xenopus oocytes injected with water (dotted bar, $n=10$ ), or expressing NaPi-IIa alone (white bar, $n=19$ ) or expressing NaPi-IIa with additional coexpression of wild-type AMPK (black bars) and incubated for the last 24 hours before measurement without (left black bar) or with (right black bar, $n=10$ ) $20 \mu \mathrm{M}$ AMPK inhibitor Compound C, or expressing NaPi-IIa alone and incubated for the last 24 hours before measurement with AMPK activator AICAR $(1 \mathrm{mM}$; grey bar, $\mathrm{n}=15)$. ${ }^{* * *}(\mathrm{p}<0.001)$ indicates statistically significant difference from Xenopus oocytes expressing NaPi-IIa alone, \#\# $(\mathrm{p}<0.01)$ indicates statistically significant difference from Xenopus oocytes expressing NaPi-IIa and wild-type AMPK (AMPK ${ }^{\alpha 1}$-HA+AMP$\mathrm{K}^{\beta 1}$-Flag+AMPK ${ }^{\gamma 1}-\mathrm{HA}$ ).

\section{Discussion}

The present study reveals a novel regulator of NaPi-IIa, i.e. the AMP-activated protein kinase AMPK. The kinase decreased the electrogenic phosphate transport mediated by NaPiIIa. The inhibition of NaPi-IIa during energy depletion lowers the $\mathrm{Na}^{+}$uptake across the apical membrane of proximal renal tubules and thus limits the requirement of $\mathrm{Na}^{+}$extrusion by the energy-consuming $\mathrm{Na}^{+} / \mathrm{K}^{+}$ATPase. Moreover, inhibition of NaPi-Ila decreases the cytosolic phosphate concentration. The decrease of $\mathrm{Na}^{+}$and phosphate entry and the prevention of $\mathrm{Na}^{+}$ and $\mathrm{Cl}^{-}$accumulation counteract cell swelling, a consequence of cellular energy depletion [11]. Accordingly, the AMPK-dependent inhibition of NaPi-IIa contributes to the protective effect of AMPK during energy depletion.

The regulation by AMPK adds to the complexity of NaPi-IIa regulation. NaPi-IIa is regulated by a variety of kinases including protein kinase $A$ [41-48], protein kinase $B$ (PKB)/ Akt $[22,27]$, protein kinase C $[43,45,46]$, protein kinase G [46], mitogen activated protein (MAP) kinases [23], extracellular receptor kinase (ERK)-1/2 [23] mammalian target of rapamycin mTOR [22, 27], glycogen synthase kinase GSK3 [27], Janus kinase JAK2 [49], 


\section{Kidney \\ Blood Pressure Research}

oxidative stress response kinase OSR [38], and STE20/SPS1-related proline/alanine-rich kinase SPAK [50]. NaPi-IIa trafficking is dependent on vacuolar $\mathrm{H}^{+}$ATPase [51] and stability of NaPi-IIa is further regulated by Klotho [26].

In contrast to phosphate transport, AMPK stimulates glucose uptake [2, 4], an effect due to activation of both, the facilitative glucose carriers GLUT1, GLUT2, GLUT3 and GLUT4 [52-63] and the $\mathrm{Na}^{+}$-coupled glucose transporter SGLT1 [64]. The uptake of glucose provides the cell with metabolic fuel. AMPK further stimulates glycolysis, fatty acid oxidation and expression of enzymes required for ATP production $[2,4]$ and thus counteracts ATP depletion.

Energy generation by glycolysis imposes a proton load on the cell by dissociation of lactic acid, and cytosolic acidification inhibits the rate-limiting enzymes of glycolysis [65]. Accordingly, glycolysis can only be maintained, as long as the generated $\mathrm{H}^{+}$ions are extruded. As a matter of fact AMPK has been shown to activate the $\mathrm{Na}^{+} / \mathrm{H}^{+}$exchanger [66].

AMPK is not only stimulated by increase in the AMP/ATP ratio, but as well by $\mathrm{Ca}^{2+}$ [1], by decrease of $\mathrm{O}_{2}$ partial pressure [67] and by increase of nitric oxide level [68]. Accordingly, alterations of cytosolic $\mathrm{Ca}^{2+}$ activity, $\mathrm{O}_{2}$ supply, and nitric oxide abundance may, at least in theory, modify NaPi-IIa activity and thus renal tubular phosphate transport.

\section{Conclusion}

The AMP-activated kinase AMPK decreases the activity of the $\mathrm{Na}^{+}$-coupled phosphate transporter NaPi-IIa and thus participates in the regulation of renal tubular phosphate transport.

\section{Conflict of Interests}

The authors state that there are no conflicts to declare.

\section{Acknowledgments}

The authors acknowledge the meticulous preparation of the manuscript by Lejla Subasic and Tanja Loch. This study was supported by the IZKF of the University of Tübingen (Nachwuchsgruppe to M. F.), the Deutsche Forschungsgemeinschaft, La315/15-1, GRK 1302, SFB 773, La 315/13-3 and the Open Access Publishing Fund of Tuebingen University.

\section{References}

1 Towler MC, Hardie DG: AMP-activated protein kinase in metabolic control and insulin signaling. Circ Res 2007;100:328-341.

-2 Winder WW, Thomson DM: Cellular energy sensing and signaling by AMP-activated protein kinase. Cell Biochem Biophys 2007;47:332-347.

-3 McGee SL, Hargreaves M: AMPK and transcriptional regulation. Front Biosci 2008;13:3022-3033.

4 Carling D: The role of the AMP-activated protein kinase in the regulation of energy homeostasis. Novartis Found Symp 2007;286:72-81.

5 Horie T, Ono K, Nagao K, Nishi H, Kinoshita M, Kawamura T, Wada H, Shimatsu A, Kita T, Hasegawa K: Oxidative stress induces GLUT4 translocation by activation of PI3-K/Akt and dual AMPK kinase in cardiac myocytes. J Cell Physiol 2008;215:733-742.

6 Jensen TE, Rose AJ, Hellsten Y, Wojtaszewski JF, Richter EA: Caffeine-induced Ca(2+) release increases AMPK-dependent glucose uptake in rodent soleus muscle. Am J Physiol Endocrinol Metab 2007;293:E286-E292. 


\section{Kidney \\ Blood Pressure Research}

7 Foller M, Sopjani M, Koka S, Gu S, Mahmud H, Wang K, Floride E, Schleicher E, Schulz E, Munzel T, Lang F: Regulation of erythrocyte survival by AMP-activated protein kinase. FASEB J 2009;23:1072-1080.

8 Hardie DG: The AMP-activated protein kinase pathway--new players upstream and downstream. J Cell Sci 2004;117:5479-5487.

9 Mandel LJ: Metabolic substrates, cellular energy production, and the regulation of proximal tubular transport. Annu Rev Physiol 1985;47:85-101.

10 Lang F, Messner G, Rehwald W: Electrophysiology of sodium-coupled transport in proximal renal tubules. Am J Physiol 1986;250:F953-F962.

11 Lang F, Busch GL, Ritter M, Volkl H, Waldegger S, Gulbins E, Haussinger D: Functional significance of cell volume regulatory mechanisms. Physiol Rev 1998;78:247-306.

12 Biber J, Hernando N, Forster I, Murer H: Regulation of phosphate transport in proximal tubules. Pflugers Arch 2009;458:39-52.

13 Murer H, Forster I, Biber J: The sodium phosphate cotransporter family SLC34. Pflugers Arch 2004;447:763-767.

14 Villa-Bellosta R, Ravera S, Sorribas V, Stange G, Levi M, Murer H, Biber J, Forster IC: The Na+-Pi cotransporter PiT-2 (SLC20A2) is expressed in the apical membrane of rat renal proximal tubules and regulated by dietary Pi. Am J Physiol Renal Physiol 2009;296:F691-F699.

15 Allon M: Effects of insulin and glucose on renal phosphate reabsorption: interactions with dietary phosphate. J Am Soc Nephrol 1992;2:1593-1600.

16 DeFronzo RA, Goldberg M, Agus ZS: The effects of glucose and insulin on renal electrolyte transport. J Clin Invest 1976;58:83-90.

17 Feld S, Hirschberg R: Insulinlike growth factor I and the kidney. Trends Endocrinol Metab 1996; 7:85-93.

$\checkmark 18$ Jehle AW, Forgo J, Biber J, Lederer E, Krapf R, Murer H: IGF-I and vanadate stimulate Na/Pi-cotransport in OK cells by increasing type II Na/Pi-cotransporter protein stability. Pflugers Arch 1998;437:149-154.

$\checkmark 19$ Murer H, Hernando N, Forster I, Biber J: Proximal tubular phosphate reabsorption: molecular mechanisms. Physiol Rev 2000;80:1373-1409.

20 Nowik M, Picard N, Stange G, Capuano P, Tenenhouse HS, Biber J, Murer H, Wagner CA: Renal phosphaturia during metabolic acidosis revisited: molecular mechanisms for decreased renal phosphate reabsorption. Pflugers Arch 2008;457:539-549.

-21 Picard N, Capuano P, Stange G, Mihailova M, Kaissling B, Murer H, Biber J, Wagner CA: Acute parathyroid hormone differentially regulates renal brush border membrane phosphate cotransporters. Pflugers Arch 2010;460:677-687.

-22 Kempe DS, Ackermann TF, Boini KM, Klaus F, Umbach AT, Dermaku-Sopjani M, Judenhofer MS, Pichler BJ, Capuano P, Stange G, Wagner CA, Birnbaum MJ, Pearce D, Foller M, Lang F: Akt2/PKBbeta-sensitive regulation of renal phosphate transport. Acta Physiol (Oxf) 2010;200:75-85.

-23 Bacic D, Schulz N, Biber J, Kaissling B, Murer H, Wagner CA: Involvement of the MAPK-kinase pathway in the PTH-mediated regulation of the proximal tubule type IIa Na+/Pi cotransporter in mouse kidney. Pflugers Arch 2003;446:52-60.

-24 Bacic D, LeHir M, Biber J, Kaissling B, Murer H, Wagner CA: The renal Na+/phosphate cotransporter NaPiIIa is internalized via the receptor-mediated endocytic route in response to parathyroid hormone. Kidney Int 2006;69:495-503.

-25 Bhandaru M, Kempe DS, Rotte A, Capuano P, Pathare G, Sopjani M, Alesutan I, Tyan L, Huang DY, Siraskar B, Judenhofer MS, Stange G, Pichler BJ, Biber J, Quintanilla-Martinez L, Wagner CA, Pearce D, Foller M, Lang F: Decreased bone density and increased phosphaturia in gene-targeted mice lacking functional serum- and glucocorticoid-inducible kinase 3. Kidney Int 2011;80:61-67.

26 Dermaku-Sopjani M, Sopjani M, Saxena A, Shojaiefard M, Bogatikov E, Alesutan I, Eichenmuller M, Lang F: Downregulation of NaPi-IIa and NaPi-IIb Na-coupled phosphate transporters by coexpression of Klotho. Cell Physiol Biochem 2011;28:251-258.

-27 Foller M, Kempe DS, Boini KM, Pathare G, Siraskar B, Capuano P, Alesutan I, Sopjani M, Stange G, Mohebbi N, Bhandaru M, Ackermann TF, Judenhofer MS, Pichler BJ, Biber J, Wagner CA, Lang F: PKB/SGK-resistant GSK3 enhances phosphaturia and calciuria. J Am Soc Nephrol 2011;22:873-880.

28 Hu MC, Shi M, Zhang J, Pastor J, Nakatani T, Lanske B, Razzaque MS, Rosenblatt KP, Baum MG, M K-o, Moe OW: Klotho: a novel phosphaturic substance acting as an autocrine enzyme in the renal proximal tubule. FASEB J 2010;24:3438-3450. 


\section{Kidney \\ Blood Pressure Research}

29 Kempe DS, Dermaku-Sopjani M, Frohlich H, Sopjani M, Umbach A, Puchchakayala G, Capasso A, Weiss F, Stubs M, Foller M, Lang F: Rapamycin-induced phosphaturia. Nephrol Dial Transplant 2010;25:2938-2944.

-30 Hosseinzadeh Z, Bhavsar SK, Lang F: Down-regulation of the myoinositol transporter SMIT by JAK2. Cell Physiol Biochem 2012;30:1473-1480.

-31 Busch AE, Wagner CA, Schuster A, Waldegger S, Biber J, Murer H, Lang F: Properties of electrogenic Pi transport by a human renal brush border Na+/Pi transporter. J Am Soc Nephrol 1995;6:1547-1551.

-32 Fraser SA, Gimenez I, Cook N, Jennings I, Katerelos M, Katsis F, Levidiotis V, Kemp BE, Power DA: Regulation of the renal-specific Na+-K+-2Cl- co-transporter NKCC2 by AMP-activated protein kinase (AMPK). Biochem J 2007;405:85-93.

33 Mia S, Munoz C, Pakladok T, Siraskar G, Voelkl J, Alesutan I, Lang F: Downregulation of Kv1.5 K channels by the AMP-activated protein kinase. Cell Physiol Biochem 2012;30:1039-1050.

34 Hamilton SR, Stapleton D, O'Donnell JB, Jr., Kung JT, Dalal SR, Kemp BE, Witters LA: An activating mutation in the gamma1 subunit of the AMP-activated protein kinase. FEBS Lett 2001;500:163-168.

-35 Hallows KR, Kobinger GP, Wilson JM, Witters LA, Foskett JK: Physiological modulation of CFTR activity by AMP-activated protein kinase in polarized T84 cells. Am.J Physiol Cell Physiol 2003;284:C1297-C1308.

-36 Hosseinzadeh Z, Bhavsar SK, Lang F: Downregulation of ClC-2 by JAK2. Cell Physiol Biochem 2012;29:737742 .

-37 Strutz-Seebohm N, Pusch M, Wolf S, Stoll R, Tapken D, Gerwert K, Attali B, Seebohm G: Structural basis of slow activation gating in the cardiac I Ks channel complex. Cell Physiol Biochem 2011;27:443-452.

-38 Pathare G, Foller M, Daryadel A, Mutig K, Bogatikov E, Fajol A, Almilaji A, Michael D, Stange G, Voelkl J, Wagner CA, Bachmann S, Lang F: OSR1-sensitive renal tubular phosphate reabsorption. Kidney Blood Press Res 2012;36:149-161.

-39 Bogatikov E, Munoz C, Pakladok T, Alesutan I, Shojaiefard M, Seebohm G, Foller M, Palmada M, Bohmer C, Broer S, Lang F: Up-regulation of amino acid transporter SLC6A19 activity and surface protein abundance by PKB/Akt and PIKfyve. Cell Physiol Biochem 2012;30:1538-1546.

-40 Henrion U, Zumhagen S, Steinke K, Strutz-Seebohm N, Stallmeyer B, Lang F, Schulze-Bahr E, Seebohm G: Overlapping cardiac phenotype associated with a familial mutation in the voltage sensor of the KCNQ1 channel. Cell Physiol Biochem 2012;29:809-818.

41 Yamada F, Horie D, Nakamura A, Tanimura A, Yamamoto H, Segawa H, Ito M, Miyamoto K, Taketani Y, Takeda E: Role of serine 249 of ezrin in the regulation of sodium-dependent phosphate transporter NaPiIla activity in renal proximal tubular cells. J Med Invest 2013;60:27-34.

42 Guo J, Song L, Liu M, Segawa H, Miyamoto K, Bringhurst FR, Kronenberg HM, Juppner H: Activation of a non-cAMP/PKA signaling pathway downstream of the PTH/PTHrP receptor is essential for a sustained hypophosphatemic response to PTH infusion in male mice. Endocrinology 2013;154:1680-1689.

-43 Capuano P, Bacic D, Roos M, Gisler SM, Stange G, Biber J, Kaissling B, Weinman EJ, Shenolikar S, Wagner CA, Murer H: Defective coupling of apical PTH receptors to phospholipase C prevents internalization of the Na+-phosphate cotransporter NaPi-IIa in Nherf1-deficient mice. Am.J Physiol Cell Physiol 2007;292:C927-C934.

-44 Honegger KJ, Capuano P, Winter C, Bacic D, Stange G, Wagner CA, Biber J, Murer H, Hernando N: Regulation of sodium-proton exchanger isoform 3 (NHE3) by PKA and exchange protein directly activated by cAMP (EPAC). Proc Natl Acad Sci USA 2006;103:803-808.

45 Nashiki K, Taketani Y, Takeichi T, Sawada N, Yamamoto H, Ichikawa M, Arai H, Miyamoto K, Takeda E: Role of membrane microdomains in PTH-mediated down-regulation of NaPi-IIa in opossum kidney cells. Kidney Int 2005;68:1137-1147.

46 Capuano P, Bacic D, Stange G, Hernando N, Kaissling B, Pal R, Kocher O, Biber J, Wagner CA, Murer H: Expression and regulation of the renal $\mathrm{Na}$ /phosphate cotransporter NaPi-IIa in a mouse model deficient for the PDZ protein PDZK1. Pflugers Arch 2005;449:392-402.

47 Gisler SM, Madjdpour C, Bacic D, Pribanic S, Taylor SS, Biber J, Murer H: PDZK1: II. an anchoring site for the PKA-binding protein D-AKAP2 in renal proximal tubular cells. Kidney Int 2003;64:1746-1754.

-48 Lederer ED, Khundmiri SJ, Weinman EJ: Role of NHERF-1 in regulation of the activity of Na-K ATPase and sodium-phosphate co-transport in epithelial cells. J Am Soc Nephrol 2003;14:1711-1719.

-49 Shojaiefard M, Hosseinzadeh Z, Pakladok T, Bhavsar SK, Lang F: Stimulation of Na(+) coupled phosphate transporter NaPiIla by janus kinase JAK2. Biochem Biophys Res Commun 2013;431:186-191. 


\section{Kidney \\ Blood Pressure Research}

50 Pathare G, Foller M, Michael D, Walker B, Hierlmeier M, Mannheim JG, Pichler BJ, Lang F: Enhanced FGF23 serum concentrations and phosphaturia in gene targeted mice expressing WNK-resistant SPAK. Kidney Blood Press Res 2012;36:355-364.

-51 Ahmad A, Khundmiri SJ, Pribble F, Merchant ML, Ameen M, Klein JB, Levi M, Lederer ED: Role of vacuolar ATPase in the trafficking of renal type IIa sodium-phosphate cotransporter. Cell Physiol Biochem 2011;27:703-714.

-52 Guan F, Yu B, Qi GX, Hu J, Zeng DY, Luo J: Chemical hypoxia-induced glucose transporter-4 translocation in neonatal rat cardiomyocytes. Arch Med Res 2008;39:52-60.

-53 Jessen N, Pold R, Buhl ES, Jensen LS, Schmitz O, Lund S: Effects of AICAR and exercise on insulin-stimulated glucose uptake, signaling, and GLUT-4 content in rat muscles. J Appl Physiol 2003;94:1373-1379.

54 Lei B, Matsuo K, Labinskyy V, Sharma N, Chandler MP, Ahn A, Hintze TH, Stanley WC, Recchia FA: Exogenous nitric oxide reduces glucose transporters translocation and lactate production in ischemic myocardium in vivo. Proc Natl Acad Sci USA 2005;102:6966-6971.

55 Li J, Hu X, Selvakumar P, Russell RR, III, Cushman SW, Holman GD, Young LH: Role of the nitric oxide pathway in AMPK-mediated glucose uptake and GLUT4 translocation in heart muscle. Am J Physiol Endocrinol Metab 2004;287:E834-E841.

-56 Luiken JJ, Coort SL, Koonen DP, van der Horst DJ, Bonen A, Zorzano A, Glatz JF: Regulation of cardiac longchain fatty acid and glucose uptake by translocation of substrate transporters. Pflugers Arch 2004;448:115.

57 MacLean PS, Zheng D, Jones JP, Olson AL, Dohm GL: Exercise-induced transcription of the muscle glucose transporter (GLUT 4) gene. Biochem Biophys Res Commun 2002;292:409-414.

58 Natsuizaka M, Ozasa M, Darmanin S, Miyamoto M, Kondo S, Kamada S, Shindoh M, Higashino F, Suhara W, Koide H, Aita K, Nakagawa K, Kondo T, Asaka M, Okada F, Kobayashi M: Synergistic up-regulation of Hexokinase-2, glucose transporters and angiogenic factors in pancreatic cancer cells by glucose deprivation and hypoxia. Exp Cell Res 2007;313:3337-3348.

59 Ojuka EO, Nolte LA, Holloszy JO: Increased expression of GLUT-4 and hexokinase in rat epitrochlearis muscles exposed to AICAR in vitro. J Appl Physiol 2000;88:1072-1075.

60 Park S, Scheffler TL, Gunawan AM, Shi H, Zeng C, Hannon KM, Grant AL, Gerrard DE: Chronic elevated calcium blocks AMPK-induced GLUT-4 expression in skeletal muscle. Am J Physiol Cell Physiol 2009;296:C106-C115.

61 Walker J, Jijon HB, Diaz H, Salehi P, Churchill T, Madsen KL: 5-aminoimidazole-4-carboxamide riboside (AICAR) enhances GLUT2-dependent jejunal glucose transport: a possible role for AMPK. Biochem J 2005;385:485-491.

62 Winder WW, Holmes BF, Rubink DS, Jensen EB, Chen M, Holloszy JO: Activation of AMP-activated protein kinase increases mitochondrial enzymes in skeletal muscle. J Appl Physiol 2000;88:2219-2226.

63 Zheng D, MacLean PS, Pohnert SC, Knight JB, Olson AL, Winder WW, Dohm GL: Regulation of muscle GLUT-4 transcription by AMP-activated protein kinase. J Appl Physiol 2001;91:1073-1083.

-64 Sopjani M, Bhavsar SK, Fraser S, Kemp BE, Foller M, Lang F: Regulation of Na+-coupled glucose carrier SGLT1 by AMP-activated protein kinase. Mol Membr Biol 2010;27:137-144.

65 Boiteux A, Hess B: Design of glycolysis. Philos Trans R Soc Lond B Biol Sci 1981;293:5-22.

66 Rotte A, Pasham V, Eichenmuller M, Bhandaru M, Foller M, Lang F: Upregulation of Na+/H+ exchanger by the AMP-activated protein kinase. Biochem Biophys Res Commun 2010;398:677-682.

67 Evans AM, Mustard KJ, Wyatt CN, Peers C, Dipp M, Kumar P, Kinnear NP, Hardie DG: Does AMP-activated protein kinase couple inhibition of mitochondrial oxidative phosphorylation by hypoxia to calcium signaling in 02-sensing cells? J Biol Chem 2005;280:41504-41511.

-68 Lira VA, Soltow QA, Long JH, Betters JL, Sellman JE, Criswell DS: Nitric oxide increases GLUT4 expression and regulates AMPK signaling in skeletal muscle. Am J Physiol Endocrinol Metab 2007;293:E1062-E1068. 